\title{
SCIENTIFIC REPORTS

\section{Determination of Heavy Metals in Herbal Food Supplements using Bismuth/Multi-walled Carbon Nanotubes/Nafion modified Graphite Electrodes sourced from Waste Batteries}

\begin{abstract}
Shirley Palisoc ${ }^{1,2}{ }^{\text {, Remuel Isaac M. Vitto }}{ }^{1}$ \& Michelle Natividad ${ }^{1,2^{*}}$
An electrochemical sensor based on graphite electrode extracted from waste zinc-carbon battery is developed. The graphite electrode was modified with bismuth nanoparticles (BiNP), multi-walled carbon nanotubes (MWCNT) and Nafion via the drop coating method. The bare and modified graphite electrodes were used as the working electrode in anodic stripping voltammetry for the determination of trace amounts of cadmium $\left(\mathrm{Cd}^{2+}\right)$ and lead $\left(\mathrm{Pb}^{2+}\right)$. The modified electrode exhibited excellent electroanalytical performance for heavy metal detection in comparison with the bare graphite electrode. The linear concentration range from 5 parts per billion $(\mathrm{ppb})$ to $1000 \mathrm{ppb}\left(\mathrm{R}^{2}=0.996\right)$, as well as detection limits of $1.06 \mathrm{ppb}$ for $\mathrm{Cd}^{2+}$ and $0.72 \mathrm{ppb}$ for $\mathrm{Pb}^{2+}$ were obtained at optimized experimental conditions and parameters. The sensor was successfully utilized for the quantification of $\mathrm{Cd}^{2+}$ and $\mathrm{Pb}^{2+}$ in herbal food supplement samples with good agreement to the results obtained by atomic absorption spectroscopy. Thus, the BiNP/MWCNT/Nafion modified graphite electrode is a cost-effective and environment-friendly sensor for monitoring heavy metal contamination.
\end{abstract}

Heavy metal pollution is mainly a result of mining and smelting operations, industrial processes, and the use of metal compounds in domestic and agricultural activities ${ }^{1,2}$. To prevent exposure of humans and animals to these toxic elements, the World Health Organization (WHO) regulates the concentrations of trace heavy metals in water, soil, plants, food, and many more. The heavy metal intake for medicinal plants, for instance, was set by WHO with the permissible limit of 0.3 parts per million ( $\mathrm{ppm}$ ) for cadmium and $10 \mathrm{ppm}$ for lead ${ }^{3}$. Due to the adverse effects of heavy metals on human health and on the environment, the determination of heavy metals has attracted considerable attention in recent years ${ }^{4-17}$. Analytical techniques such as atomic absorption spectrometry, laser-induced plasma spectroscopy, inductively coupled plasma-mass spectrometry, colorimetric analysis, high-performance liquid chromatography ${ }^{18-22}$, and electrochemical methods such as anodic stripping voltammetry (ASV) have been developed to detect trace amounts of heavy metals in samples ${ }^{23-26}$. Chromatographic and spectrophotometric methods, however, are not an ideal technique because they are expensive, they require complex process and instruments, and are time-consuming. On the other hand, electrochemical method is a fast and efficient way of determining the concentrations of heavy metals in samples due to its simplicity, high sensitivity, good stability, and low cost.

The glassy carbon electrode (GCE) is commonly used as the working electrode in voltammetry due to its high sensitivity and selectivity ${ }^{27}$. Nonetheless, the excellent properties of GCE come in exchange for its high $\operatorname{cost}^{28}$. Alternatively, graphite electrodes (GE) are ideal for the electrochemical analysis of heavy metals as they offer attractive features, such as, good electrical conductivity, low background current, and little or no pretreatment is

${ }^{1}$ Condensed Matter Physics Laboratory, De La Salle University, Manila, 922, Philippines. ${ }^{2}$ Condensed Matter Research Unit, CENSER, De La Salle University, 2401 Taft Avenue, Manila, 922, Philippines. *email: michelle. natividad@dlsu.edu.ph 


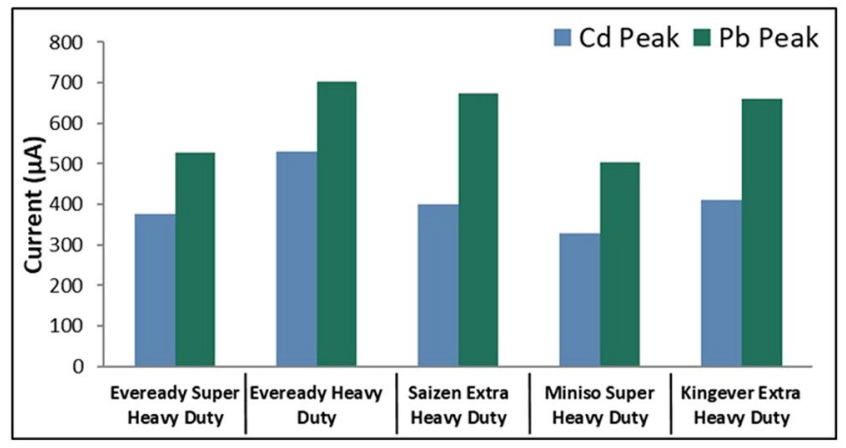

Figure 1. Anodic current peaks of graphite rods from different battery brands.

required ${ }^{29}$. Graphite can be easily obtained because it is abundantly available in waste dry-cell batteries. Eveready India Ltd. is the world's third largest producer of carbon zinc batteries which sells more than a billion units per year and with a projected increase in net sales and operating profit for the years 2018 and $2019^{30}$. Thus, access to recycled batteries will not be a problem in the coming years. Moreover, the graphite rods extracted from waste AA batteries have ideal measurements $(2 \mathrm{~mm}$ or $3 \mathrm{~mm}$ in diameter) that fit the fabrication of a good working electrode ${ }^{31}$. However, bare graphite electrodes have a certain disadvantage when used in electrochemical analysis as they usually have a low sensitivity due to their high activation overpotential ${ }^{32}$. The structure of graphite is comprised of sp2 hybridized carbon atoms, arranged in a graphene layer in a honeycomb lattice structure, and each layer has a free valence electron that enables bonding with other graphene layers and other elements through the Van der Waals interaction ${ }^{33}$. Due to this unique structure of graphite, its surface can be easily modified with various elements to increase its sensitivity.

Different materials have been employed for the modification of electrodes used in electrochemical analy$\operatorname{sis}^{34-48}$. Bismuth nanoparticles (BiNP) have become one of the most popular electrode modifiers due to its broad electrochemical window and low toxicity. Studies have shown that modification of the working electrode with bismuth has effectively improved the electrode's analytical performance in ASV compared to a bare or unmodified electrode ${ }^{49,50}$. Modification with multi-walled carbon nanotubes (MWCNT) has also been reported to increase the electrode's electrical conductivity, decrease the probability of surface fouling ${ }^{51}$, and increase the rate of electrochemical reactions ${ }^{52}$. Nafion has also been widely used as an electrode modifier because it is a perfluorinated sulphonated cation exchanger and it has excellent properties such as antifouling capacity, chemical inertness, and high permeability to cations ${ }^{53,54}$. Hence, the combination of BiNP, MWCNT, and Nafion as electrode modifiers would bring a synergistic effect that would greatly increase the selectivity and sensitivity of the electrode.

Herbal food supplements (HFS) continue to become more and more popular worldwide with a significant population turning into these products for the treatment of various health problems and/or for the augmentation of deficiencies in vitamins and minerals ${ }^{55}$. However, concerns in public health issues regarding their safety have arisen as many of them have not yet been tested and are poorly monitored. The safety is often conflicted by insufficient control in their quality, incomplete labeling, and the absence of proper user information ${ }^{56}$. Thus, their known possible adverse effects are very limited and it is difficult to determine the safest and effective way of using them. Moreover, it has been reported in some studies that some HFS contain heavy metals ${ }^{57,58}$. It is therefore important to determine possible heavy metal contamination in HFS.

The aim of this study is to develop a cost-effective and environment-friendly electrochemical sensor based on graphite rod extracted from waste zinc-carbon battery. The extracted rods were modified with BiNP, MWCNT and Nafion and were used as the working electrode in ASV to detect trace amounts of cadmium $\left(\mathrm{Cd}^{2+}\right)$ and lead $\left(\mathrm{Pb}^{2+}\right)$. To demonstrate the utility of the modified electrodes in sensing applications, real sample analysis using the modified graphite electrode was done on commercially available herbal food supplements.

\section{Methodology}

Materials and equipment. Bismuth nanopowder was procured from Luoyang Tongrun Info Technology Co., Ltd. (Luoyang City, Henan, China). Multi-walled carbon nanotubes were procured from Cheap Tubes Inc. (Cambridgeport, Vermont, USA), and Nafion solution was procured from Fuel Cell Earth (Woburn, Massachusetts, USA). Propanol, ethanol, and hydrochloric acid were procured from RCI Labscan Ltd. (Bangkok, Thailand). Cadmium chloride and lead chloride were procured from Sigma-Aldrich (Singapore) and sodium chloride was procured from Techno Pharmchem (Barakhamba, Delhi, India). A BOSCH SAE200 electronic balance (BOSCH-Wägesysteme $\mathrm{GmbH}$, Jungingen, Germany) was used to measure the amounts of bismuth nanopowder, MWCNT, cadmium chloride, lead chloride, and sodium chloride. A BANDELIN SONOREX sonicator (BANDELIN electronic GmbH \& Co. KG, Berlin, Germany) was used to clean the glassware and electrodes. The coating solutions were homogenized using a Misonix ultrasonicator (Misonix, Inc., Farmingdale, New York, USA). A THERMOLYNE 4800 furnace (Barnstead International, Dubuque, Iowa, USA) was used for drying the graphite rods and dry-ashing of the real samples. An Autolab PGSTAT128N potentiostat (MTI Corporation, Richmond, CA, USA) was utilized for the ASV measurements and an AA-6300 Shimadzu atomic absorption spectrophotometer (Shimadzu, Tokyo, Japan) was used for atomic absorption spectroscopy (AAS) analyses. A JSM-5310 JEOL scanning electrode microscope coupled with energy dispersive X-ray spectroscopy (JEOL USA Inc., Peabody, Massachusetts, USA) was used for the surface morphology and elemental analyses. A 


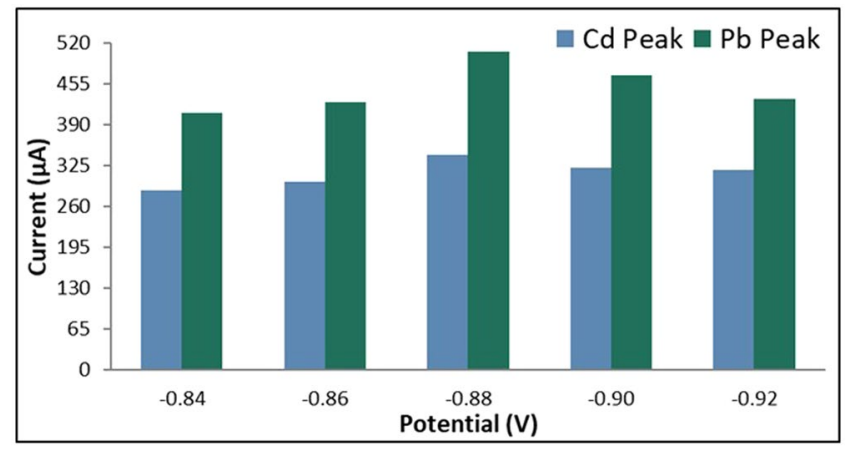

Figure 2. Anodic current peaks of bare GE for varying initial potential.

BTX-285 $\times$-ray powder diffractometer was used in the crystal structure analysis, and a Fourier transform-infrared spectrometer was utilized for the identification of the chemical components.

Preparation of graphite electrodes. The graphite rods were extracted from different commercial brands of waste zinc-carbon batteries by removing the steel casing, top and bottom terminals, paper gasket, washer, wrapper, manganese dioxide powder and zinc pieces surrounding the graphite rod ${ }^{59}$. The extracted rod was cleaned by submerging it in propanol and sonicating it for 20 minutes. Once the graphite was cleaned, it was dried in a furnace at $150^{\circ} \mathrm{C}$ for 48 hours. After drying, the tip of the electrode was polished with silicon-carbide sandpaper starting with a grade of 400 and all the way up to 5000. It was then polished with $0.3 \mu \mathrm{m}$ followed by $0.05 \mu \mathrm{m}$ alumina slurry on a glass slide. After the electrode has been polished, it was then cleaned by sonicating it for 5 minutes in ethanol, followed by deionized water and was then wrapped with Teflon tape in order to insulate the lateral exposure of the rod. The fabricated graphite electrode was kept in a desiccator at room temperature until further use.

Fabrication of modified graphite electrodes. For the preparation of BiNP-MWCNT-Nafion suspension, BiNPs and MWCNTs were weighed and were subsequently mixed with a $1 \%(\mathrm{v} / \mathrm{v})$ Nafion made of $0.333 \mathrm{ml}$ $15 \%(\mathrm{v} / \mathrm{v})$ Nafion and $4.667 \mathrm{ml}$ ethanol solution. The amounts of BiNP and MWCNT in the suspension were each varied at $0.5 \mathrm{mg}, 1.0 \mathrm{mg}$, and $1.5 \mathrm{mg}$ to determine the best combination of modifiers. The mixtures were then ultrasonicated for 2 hours. Finally, the graphite electrode was drop-coated with the BiNP-MWCNT-Nafion suspension with the use of a micropipette, and the ethanol was allowed to evaporate at room temperature in ambient air.

Preparation of stock solutions. Analyte solutions containing $0.1 \mathrm{M} \mathrm{NaCl}$ and $10 \mathrm{ppm}$ of $\mathrm{Cd}$ and $\mathrm{Pb}$ were used for the optimization of the ASV parameters. This was done by adding $1.6 \mathrm{mg}$ of $\mathrm{CdCl}_{2}, 1.3 \mathrm{mg} \mathrm{of} \mathrm{PbCl}_{2}$, and $0.5844 \mathrm{~g}$ of $\mathrm{NaCl}$ in $100 \mathrm{~mL}$ of deionized water. Ten (10) ppm solutions of $\mathrm{Cd}$ and $\mathrm{Pb}$ were used to obtain concentrations of $5 \mathrm{ppb}, 7 \mathrm{ppb}, 15 \mathrm{ppb}$, and the range from 100 to $1000 \mathrm{ppb}$ for the calibration curves. The diluted solutions were then added with $0.5844 \mathrm{~g}$ of $\mathrm{NaCl}$. All the resulting solutions were sonicated for 15 minutes.

Real sample analysis. Three samples of commercially available herbal food supplements were procured from Quiapo District, Manila. The herbal food supplements were weighed obtaining $4 \mathrm{~g}$ for each sample in a $50 \mathrm{~mL}$ quartz crucible. The samples were then prepared for analysis through the modified dry-ashing and acid digestion techniques ${ }^{60}$. The samples were dry-ashed by heating in an oven for 12 hours at $500^{\circ} \mathrm{C}$ and acid digested by dissolving them in $5 \mathrm{~mL}$ of $2.0 \mathrm{~mol} / \mathrm{L}$ of $\mathrm{HCl}$ and heated in order to evaporate the solution until dry. The residue was filtered and diluted to $200 \mathrm{~mL}$ with deionized water and sonicated for 1 hour. Finally, it was divided into two equal parts, yielding $100 \mathrm{~mL}$ solution for ASV analysis and another $100 \mathrm{~mL}$ for AAS analysis.

Anodic stripping voltammetry. Anodic stripping voltammetry was used to detect $\mathrm{Cd}^{2+}$ and $\mathrm{Pb}^{2+}$ in the prepared analyte solutions. The bare and modified graphite electrodes were used as the working electrode, an Ag/ $\mathrm{AgCl}$ electrode as the reference electrode, and a platinum wire as the counter electrode. The ASV parameters were optimized by varying the initial potential, deposition time and scan rate. The calibration curves were obtained by varying the concentrations of $\mathrm{Cd}$ and $\mathrm{Pb}$ in the electrolyte solution.

\section{Results and Discussion}

Determination of the best brand of graphite electrode. Five brands of commercial batteries were used in the simultaneous detection of $10 \mathrm{ppm}$ each of cadmium and lead via ASV. The following ASV parameters were held constant: a cleaning step at $+1 \mathrm{~V}$ for 60 seconds, a deposition potential of $-0.9 \mathrm{~V}$ for 90 seconds, a rest period for 60 seconds, and a scan rate of $0.1 \mathrm{~V} / \mathrm{s}$. Figure 1 shows that the Eveready Heavy Duty brand resulted with the highest anodic current peaks; hence, it was considered as the best brand for the detection of $\mathrm{Cd}$ and $\mathrm{Pb}$ in this study. The electrode was further optimized by determining which polishing step will result in the highest anodic current peaks for $\mathrm{Cd}$ and $\mathrm{Pb}$ by comparing the effects of different grades of sandpaper and alumina slurry. The sandpaper grade of the final polish was varied at 2000-, 5000-, and 7000-grit and unpolished electrodes and 


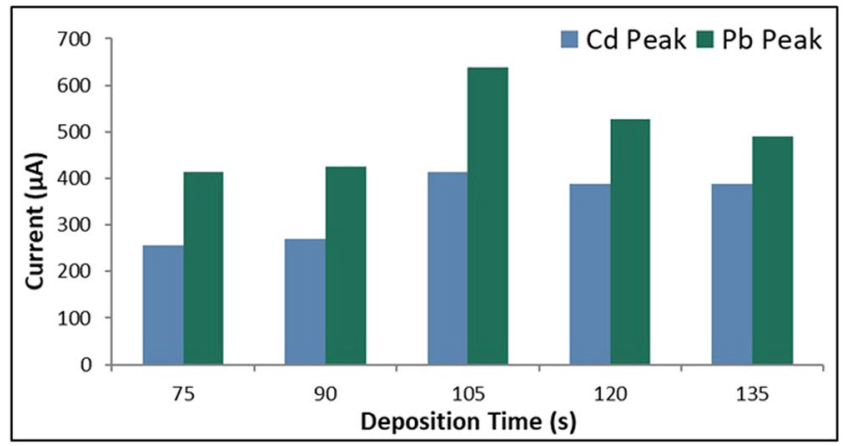

Figure 3. Anodic current peaks of bare GE for varying deposition time.

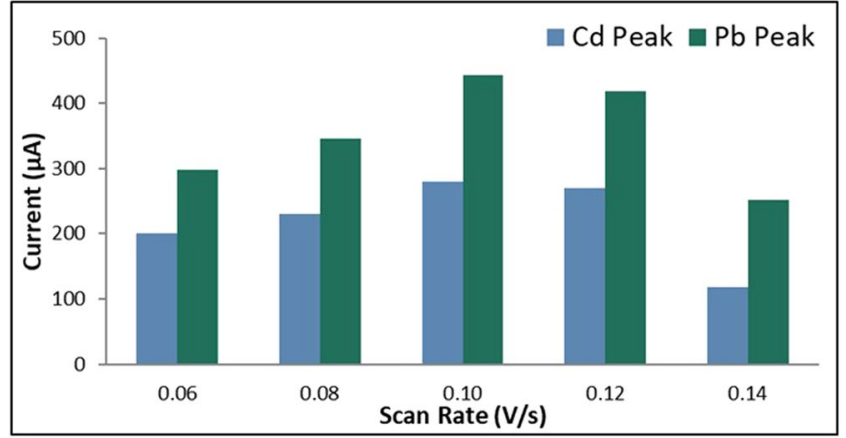

Figure 4. Anodic current peaks of bare GE for varying scan rate.

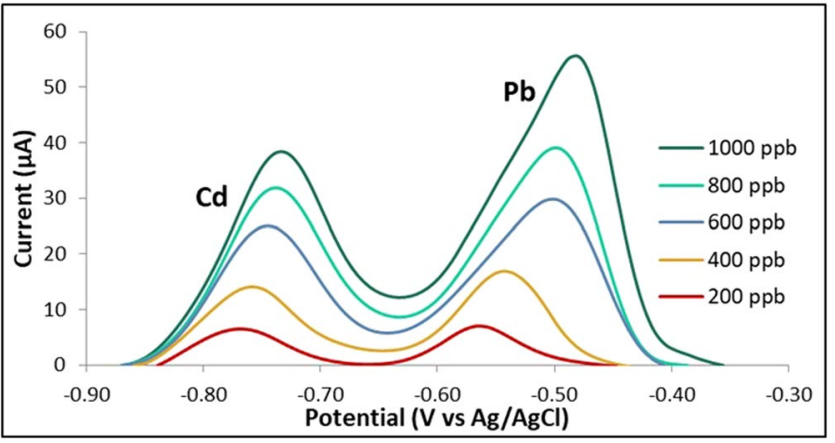

Figure 5. Voltammograms of bare $\mathrm{GE}$ for varying $\mathrm{Cd}$ and $\mathrm{Pb}$ concentrations.

electrodes polished with $0.3 \mu \mathrm{m}$ and $0.05 \mu \mathrm{m}$ alumina slurry were studied. The electrode polished with the 5000grit sandpaper, $0.3 \mu \mathrm{m}$ and $0.05 \mu \mathrm{m}$ alumina slurry resulted in a higher anodic current peak.

Optimization of anodic stripping voltammetry parameters for bare graphite electrode. Initial potential. The applied initial potential was varied at $-0.84 \mathrm{~V},-0.86 \mathrm{~V},-0.88 \mathrm{~V},-0.90 \mathrm{~V}$, and $-0.92 \mathrm{~V}$. The deposition time was held constant at $90 \mathrm{~s}$, the rest period at $60 \mathrm{~s}$, and the scan rate at $0.1 \mathrm{~V} / \mathrm{s}$. Figure 2 shows that the anodic current peaks for both $\mathrm{Cd}$ and $\mathrm{Pb}$ increased as the initial potential was decreased from $-0.84 \mathrm{~V}$ to $-0.88 \mathrm{~V}$, while a significant decrease in the response of the anodic current peaks were observed when the initial potential reached a potential more negative than $-0.88 \mathrm{~V}$. This phenomenon could be ascribed to the evolution of hydrogen ions as the initial potential became more negative ${ }^{61}$. Therefore, the potential of $-0.88 \mathrm{~V}$ was considered to be the optimum initial potential in this study.

Deposition time. The applied deposition time was varied at $75 \mathrm{~s}, 90 \mathrm{~s}, 105 \mathrm{~s}, 120 \mathrm{~s}$, and $135 \mathrm{~s}$. The rest period was held constant at $60 \mathrm{~s}$, the scan rate at $0.1 \mathrm{~V} / \mathrm{s}$, and the initial potential at $-0.88 \mathrm{~V}$. It can be observed in Fig. 3 that an increase in the current peaks for both $\mathrm{Cd}$ and $\mathrm{Pb}$ occurred as the deposition time was increased from $75 \mathrm{~s}$ to $105 \mathrm{~s}$. This is due to the increase in the amounts of analytes adsorbed on the surface of the electrode as the deposition time was increased. However, a significant drop in the anodic current peaks was observed when the 


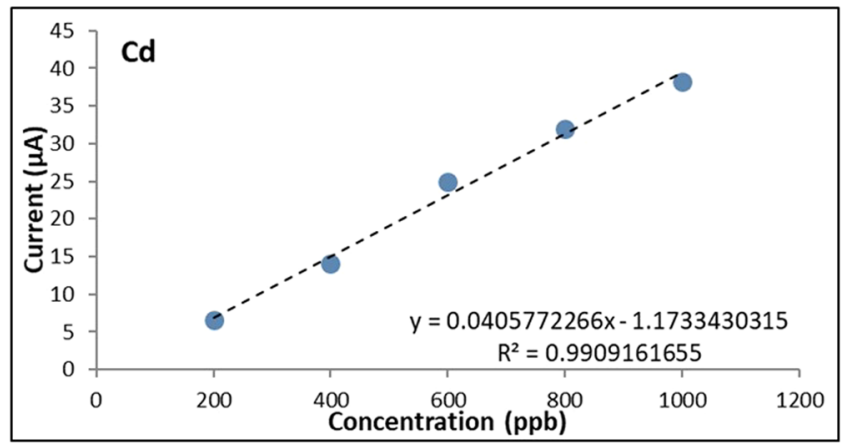

Figure 6. Calibration curve of bare GE for Cd.

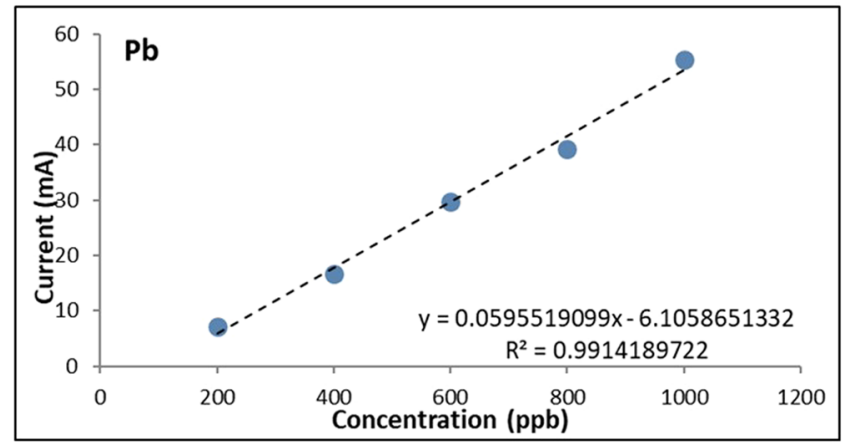

Figure 7. Calibration curve of bare GE for $\mathrm{Pb}$.

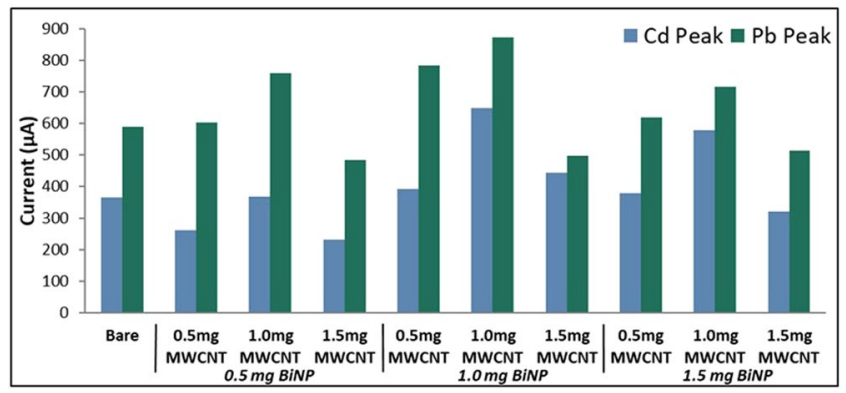

Figure 8. Anodic current peaks for varying amounts of modifiers.

deposition time was further increased which can be attributed to the saturation of the electrode's surface with Cd and $\mathrm{Pb}$ ions $\mathrm{s}^{62}$. Therefore, the optimum deposition time was determined to be $105 \mathrm{~s}$.

Scan rate. The applied scan rate was varied at $0.06 \mathrm{~V} / \mathrm{s}, 0.08 \mathrm{~V} / \mathrm{s}, 0.10 \mathrm{~V} / \mathrm{s}, 0.12 \mathrm{~V} / \mathrm{s}$, and $0.14 \mathrm{~V} / \mathrm{s}$. The rest period was held constant at $60 \mathrm{~s}$, the initial potential at $-0.88 \mathrm{~V}$ and the deposition time at $105 \mathrm{~s}$. Figure 4 shows that the anodic current peaks for both $\mathrm{Cd}$ and $\mathrm{Pb}$ increased as the scan rate was increased from $0.06 \mathrm{~V} / \mathrm{s}$ to $0.10 \mathrm{~V} / \mathrm{s}$. Increasing the scan rate further resulted in a decrease in the current peaks. This is due to the heavy metal cations that readily form a cationic complex which is adsorbed by the Nafion cation-exchanger film. At higher scan rates, the complex cations are not completely reduced resulting to a lower current peak ${ }^{63}$. The best scan rate, therefore, was determined to be $0.10 \mathrm{~V} / \mathrm{s}$.

Calibration curves for bare graphite electrode. The calibration curves were obtained by varying the concentrations of $\mathrm{Cd}$ and $\mathrm{Pb}$ from $100 \mathrm{ppb}$ to $1000 \mathrm{ppb}$ (Figs. 5, 6 and 7). The calculated values for $\mathrm{R} 2$ were found to be 0.9901 for $\mathrm{Cd}$ and 0.9914 for $\mathrm{Pb}$ which indicate a strong linear relationship between the heavy metal concentration and the anodic current peak.

Optimization of modified graphite electrode. The amount of BiNP was varied at $0.5 \mathrm{mg}, 1.0 \mathrm{mg}$, and $1.5 \mathrm{mg}$ while that of MWCNT was varied at $0.5 \mathrm{mg}, 1.0 \mathrm{mg}$, and $1.5 \mathrm{mg}$. The concentration of the Nafion solution containing $0.333 \mathrm{~mL}$ of $15 \mathrm{wt} . \%$ Nafion and $4.667 \mathrm{~mL}$ of laboratory-grade ethanol was held constant. The resulting modified electrodes were used in the simultaneous detection of $10 \mathrm{ppm}$ each of cadmium and lead via ASV. The 


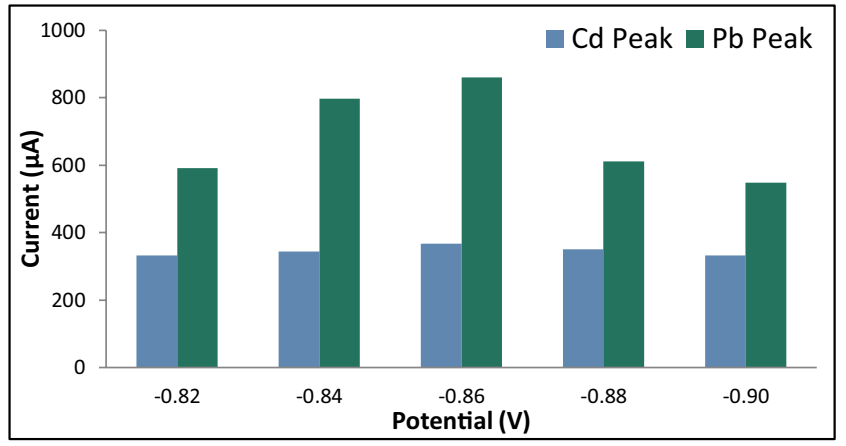

Figure 9. Anodic current peaks of modified GE for varying initial potential.

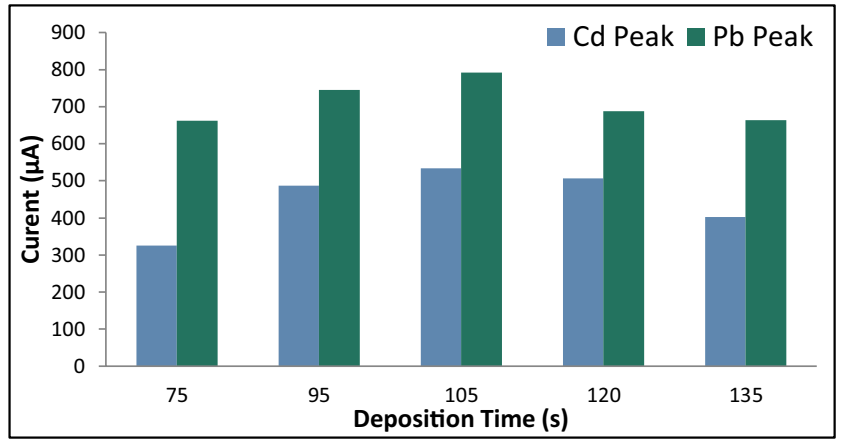

Figure 10. Anodic current peaks of modified GE for varying deposition time.

following ASV parameters were held constant: a cleaning step of $+1 \mathrm{~V}$ for $60 \mathrm{~s}$, an initial potential of $-0.88 \mathrm{~V}$, deposition time of $105 \mathrm{~s}$, a rest period for $60 \mathrm{~s}$, and a scan rate of $0.1 \mathrm{~V} / \mathrm{s}$. The anodic current peaks showed an increasing trend as the amounts of BiNP and MWCNT were increased from $0.5 \mathrm{mg}$ to $1.0 \mathrm{mg}$ as seen in Fig. 8. However, a significant decrease in the anodic current peaks for both heavy metals was observed as the amounts of BiNP and MWCNT were further increased further which can be ascribed to the oversaturation of the modifiers on the electrode surface. This resulted in a thick layer of the modifiers on the electrode surface which consequently suppressed its conducting capabilities. Since the electrode modified with $1.0 \mathrm{mg}$ of BiNP and MWCNT exhibited the highest anodic current peaks for both $\mathrm{Cd}$ and $\mathrm{Pb}$, it was chosen to be the best modified electrode in this study. The surface modification of the electrode significantly increased the anodic peaks for both heavy metals as compared to the bare electrode, as seen in Fig. 8. This can be attributed to the synergetic effects of BiNP, MWCNT and Nafion. The high conductivity and surface area-to-volume ratio of BiNPs and MWCNT increased the number of active sites within the electrode resulting to an increase in the amount of metal ions deposited on the electrode's surface while the antifouling and cationic exchange capabilities of Nafion improved the stability of the electrode. In addition, for any amount of BiNP, the anodic current peaks for both $\mathrm{Cd}$ and $\mathrm{Pb}$ appear to be the highest when the amount of MWCNT is $1.0 \mathrm{mg}$, followed by $0.5 \mathrm{mg}$, and the lowest at $1.5 \mathrm{mg}$, except for the electrode modified with $1.0 \mathrm{mg}$ BiNP and $0.5 \mathrm{mg}$ MWCNT.

Optimization of anodic stripping voltammetry parameters for modified graphite electrode. Initial potential. The initial potential was varied at $-0.82 \mathrm{~V},-0.84 \mathrm{~V},-0.86 \mathrm{~V},-0.88 \mathrm{~V}$, and $-0.90 \mathrm{~V}$ while the deposition time was held constant at $105 \mathrm{~s}$, the rest period at $60 \mathrm{~s}$, and the scan rate at $0.1 \mathrm{~V} / \mathrm{s}$. The anodic current peaks for $\mathrm{Pb}$ was observed to increase as the initial potential was decreased from $-0.82 \mathrm{~V}$ to $-0.86 \mathrm{~V}$ and decreased as the initial potential became more negative (Fig. 9). Hence, the initial potential of $-0.86 \mathrm{~V}$ was considered to be the optimum potential. It can also be observed from Fig. 10 that the current peak for Cd did not vary much as the initial potential was varied. This is probably due to the preferred sensitivity of bismuth to $\mathrm{Pb}^{2^{+}}$since the electronegativity of lead does not differ significantly from that of bismuth as compared to the difference between the electronegativities of cadmium and bismuth $^{64}$.

Deposition time. The deposition time was varied at 75 s, 90 s, 105 s, 120 s, and $135 \mathrm{~s}$. The other ASV parameters were held constant where the rest period was $60 \mathrm{~s}$ and the scan rate was $0.1 \mathrm{~V} / \mathrm{s}$ and the initial potential was $-0.86 \mathrm{~V}$ since its optimal value was already determined. An increase in the current peaks of $\mathrm{Cd}$ and $\mathrm{Pb}$ was observed as the deposition time was increased from $75 \mathrm{~s}$ to $105 \mathrm{~s}$ (Fig. 10). However, a deposition time of more than $105 \mathrm{~s}$ significantly decreases the current response peaks of $\mathrm{Cd}$ and $\mathrm{Pb}$. Again, this is due to the huge amounts of the analytes that oversaturates the electrode's surface ${ }^{38}$. A shift in the reduction potentials of $\mathrm{Pb}$ and $\mathrm{Cd}$ to a 


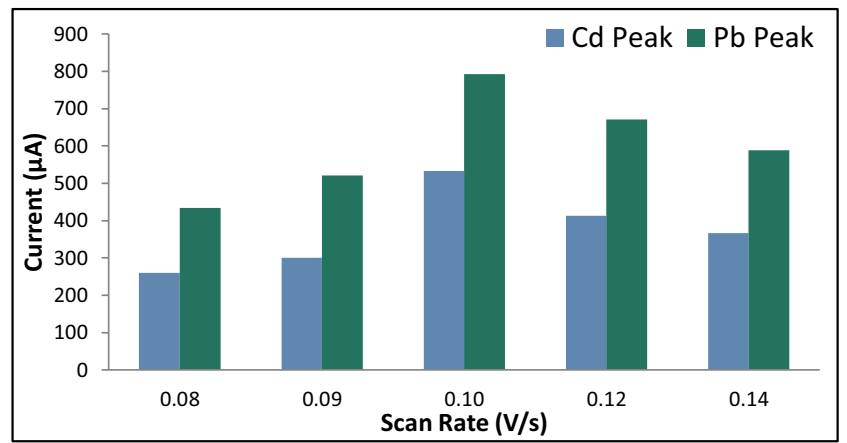

Figure 11. Anodic current peaks of modified GE for varying scan rate.

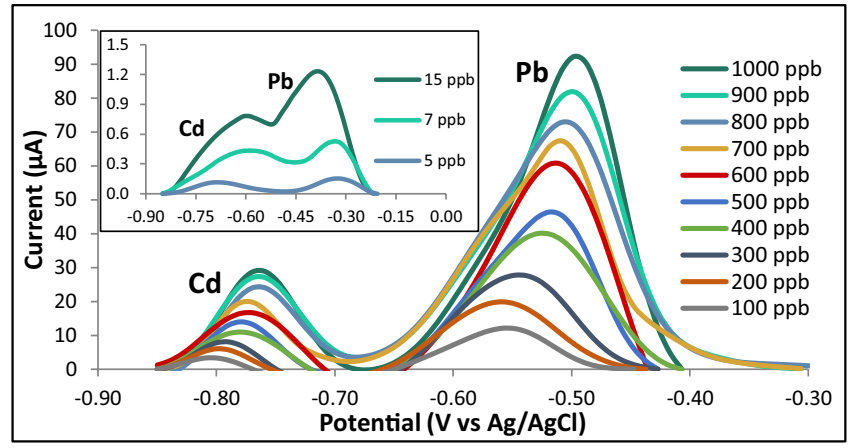

Figure 12. Voltammograms of the optimized modified GE for with varying analyte concentrations.

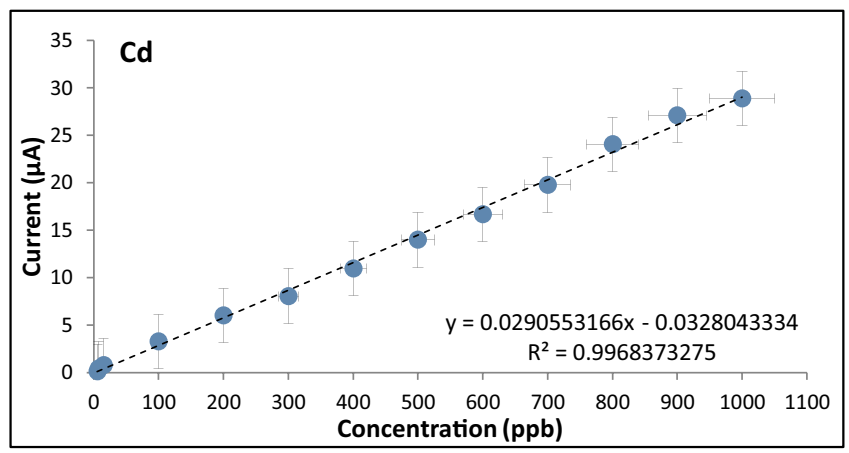

Figure 13. Calibration Curve of the optimized modified GE for Cd.

more cathodic potential was visible in the voltammograms, which was due to the increased amounts of the analytes which resulted to a higher potential needed to reduce the analytes ${ }^{40}$. Therefore, the optimal deposition time was determined to be $105 \mathrm{~s}$.

Scan rate. The scan rate was varied at $0.06 \mathrm{~V} / \mathrm{s}, 0.08 \mathrm{~V} / \mathrm{s}, 0.10 \mathrm{~V} / \mathrm{s}, 0.12 \mathrm{~V} / \mathrm{s}$, and $0.14 \mathrm{~V} / \mathrm{s}$. The rest period was held constant at $60 \mathrm{~s}$, the initial potential at $-0.86 \mathrm{~V}$, and the deposition time at $105 \mathrm{~s}$. Figure 11 suggests that the optimum scan rate is $0.10 \mathrm{~V} / \mathrm{s}$. The shift in the reduction potentials is due to the fact that as the scan rate decreases, the analytes diffuses farther from the electrode surface. As a result, the reduction of $\mathrm{Cd}^{2+}$ and $\mathrm{Pb}^{2+}$ requires a more negative potential ${ }^{65}$.

Calibration curves for the optimized modified graphite electrode. The calibration curves were obtained by varying the analyte concentrations from $5 \mathrm{ppb}$ to $1000 \mathrm{ppb}$ for both cadmium and lead (Figs. 12, 13, 14). The $\mathrm{R}^{2}$ values were found to be 0.9968 for $\mathrm{Cd}$ and 0.9965 for $\mathrm{Pb}$ indicating a strong linear relationship between the heavy metal concentration and the anodic current peak.

Characterization of the optimized modified graphite electrode. Surface morphology analysis. The modified electrode's surface morphology was studied with the use of a scanning electron microscope (SEM). Figure 15 shows the successful deposition of a web-like structure of MWCNT on the electrode's surface and the 


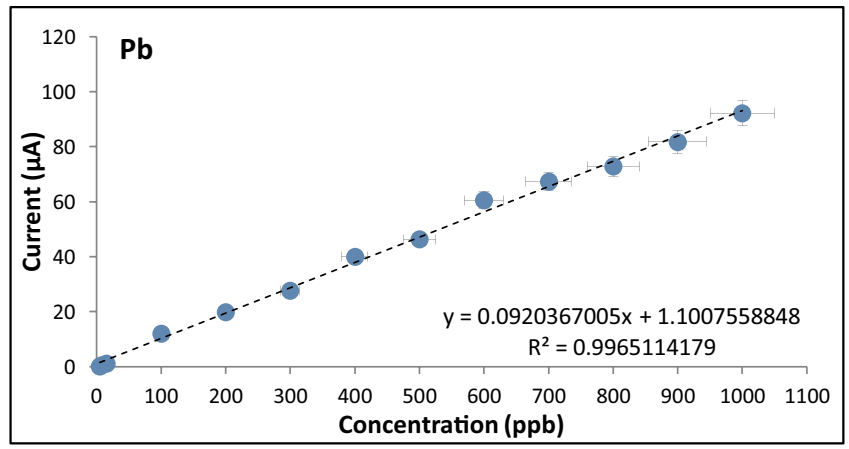

Figure 14. Calibration curve of the optimized modified GE for $\mathrm{Pb}$.
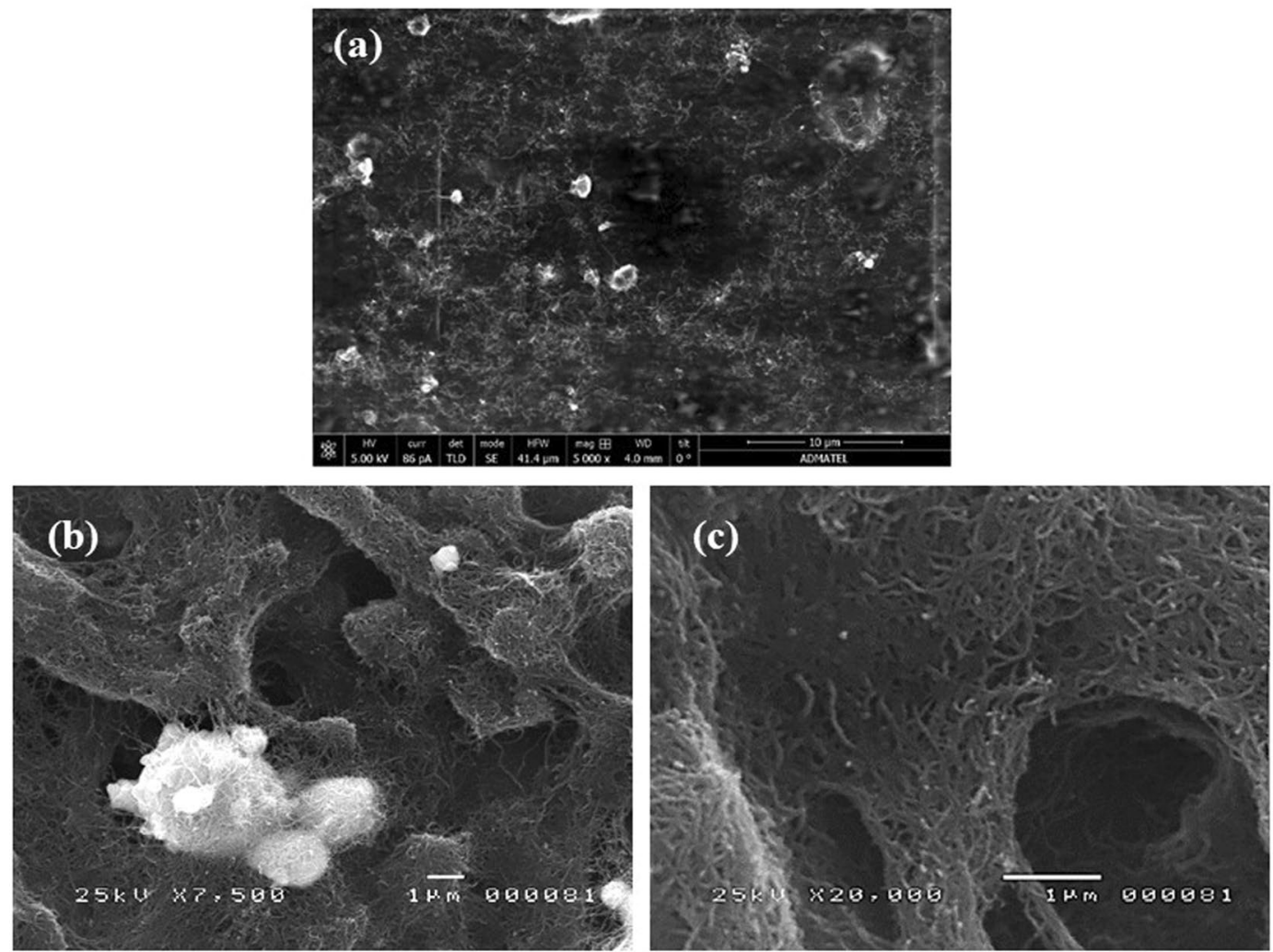

Figure 15. SEM micrographs of the optimized modified GE (a) at 5,000x magnification, (b) at 7,500x magnification, and (c) at 20,000x magnification.

MWCNT matrix's ability to act as a binding agent for the BiNPs. In addition, the uniform coating of dispersed bead-shaped BiNPs can be seen in Fig. 15b,c. For comparison, the surface morphology of the bare graphite electrode was studied at 10,000 magnification. Figure 16 shows the bare graphite electrode's surface with the natural flaky morphology of the graphite rod but without the presence of BiNPs and MWCNTs.

Elemental analysis and mapping. The modified electrode was subjected to Energy Dispersive X-ray (EDX) analysis to confirm the elemental compositions of the modifiers. Figure 17 shows the elemental mapping and the corresponding EDX spectrum of the optimized modified GE. Both the map and the spectrum confirm the presence of the modifiers on the electrode surface. The high weight percentage of fluorine $(\mathrm{F})$ is due to the presence of Nafion while the high amount of carbon (C) is due to the MWCNTs and the graphite electrode itself. The bead-shaped particles in the SEM micrographs were indeed BiNPs as revealed by the elemental mapping and the presence of bismuth in the EDX spectrum.

Real sample analysis. Real sample analysis via ASV was done using the optimized modified graphite electrode and optimum ASV parameters. The concentrations of heavy metals in the real samples were determined 

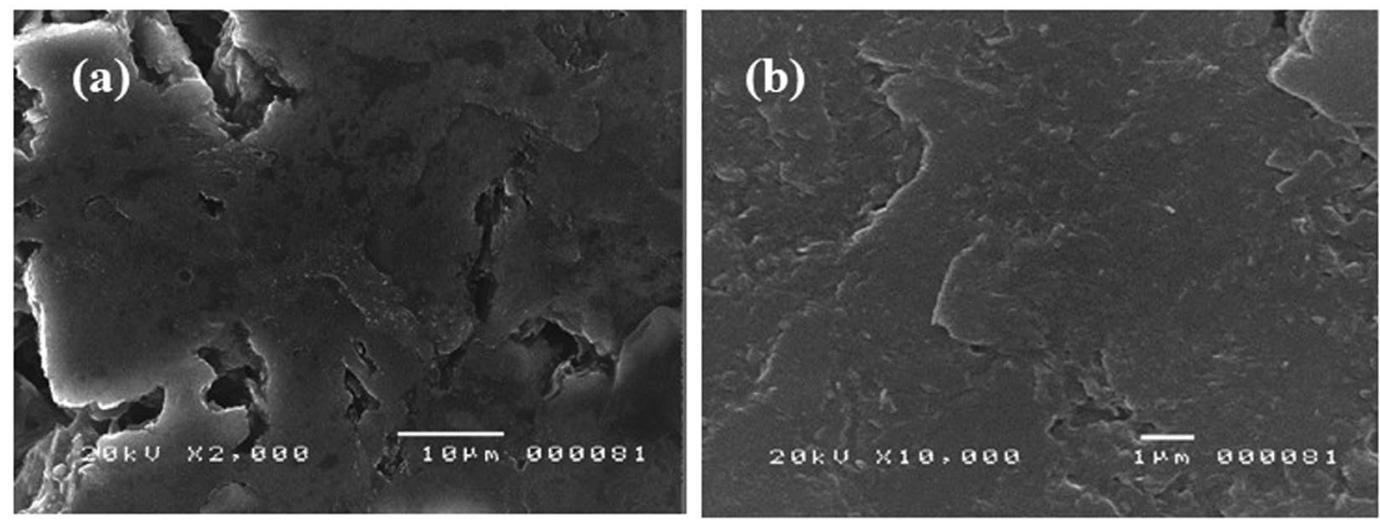

Figure 16. SEM micrographs of the bare GE (a) 2,000x magnification and (b) at 10,000x magnification.
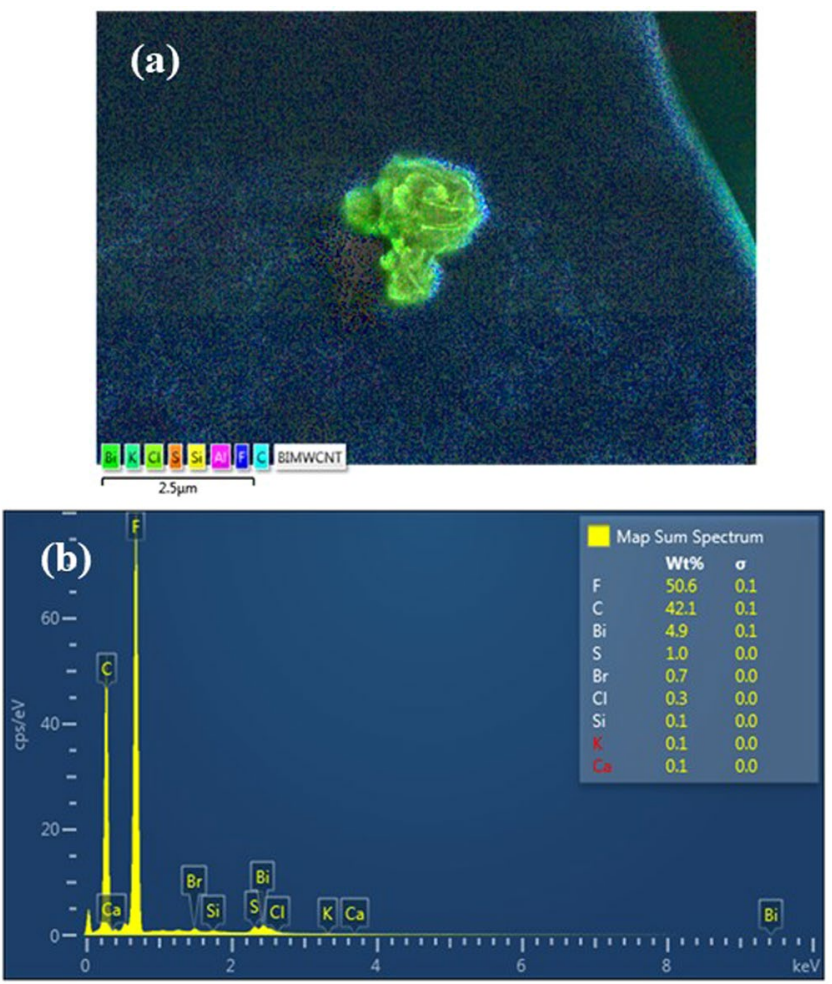

Figure 17. (a) Elemental mapping and (b) EDX spectrum of the optimized modified GE.

by substituting the values of the current peak as the $y$-values in the equations from the calibration curves of Cd and $\mathrm{Pb}$. Atomic absorption spectrometry (AAS) analysis of the real samples was carried out to verify the results obtained from ASV. The concentrations of the heavy metals in the real samples were determined by substituting the values of the absorbance as the $y$-values in the equations from the calibration curves of $\mathrm{Cd}$ and $\mathrm{Pb}$.

The results of real sample analysis via ASV and AAS were compared by computing the mean and standard deviation (Table 1). The detected concentrations of $\mathrm{Cd}$ from the voltammetric analysis were very similar to the results from AAS except for the Guyabano Herbal Tea. Due to the insignificant difference in the detected concentrations of $\mathrm{Cd}$ between the two methods, the fabricated modified electrode is proven to be as reliable as AAS for the detection of $\mathrm{Cd}$. However, the concentrations of lead in the samples were not as close as compared to cadmium. This was probably due to the inhomogeneity of the assay when the AAS measurements were taken. Nevertheless, the voltammetric results of the analysis of the real samples prove the advantage of ASV as compared to AAS since it was able to detect other heavy metals from the real samples without prior knowledge of the presence of heavy metals in the sample, i.e., Cu ions were detected in the real samples. While in AAS, the heavy metals present in the sample must be known before they are detected and quantified. 


\begin{tabular}{|l|l|l|c|l|}
\hline \multirow{2}{*}{ Sample Name } & \multicolumn{3}{|l|}{ CADMIUM } & \multicolumn{2}{l|}{ LEAD } \\
\cline { 2 - 5 } & ASV $(\mathbf{p p b})$ & AAS $(\mathbf{p p b})$ & ASV $(\mathbf{p p b})$ & AAS $(\mathbf{p p b})$ \\
\hline Banaba & $244.50 \pm 1.86$ & $234.85 \pm 0.87$ & $16.88 \pm 0.63$ & $473.43 \pm 1.40$ \\
\hline Bignay & $230.17 \pm 1.69$ & $238.52 \pm 0.68$ & $9.29 \pm 0.62$ & $521.29 \pm 6.40$ \\
\hline Guyabano & $109.39 \pm 2.50$ & $263.70 \pm 1.40$ & $235.91 \pm 8.17$ & $611.87 \pm 12.17$ \\
\hline
\end{tabular}

Table 1. Comparison of Detected Concentrations of $\mathrm{Cd}$ and $\mathrm{Pb}$ in real samples.

\begin{tabular}{|c|c|c|c|c|c|c|}
\hline \multirow[b]{2}{*}{ Electrode } & \multirow[b]{2}{*}{ Modifiers } & \multirow[b]{2}{*}{ Method } & \multirow{2}{*}{$\begin{array}{l}\text { Heavy } \\
\text { Metals } \\
\text { Detected }\end{array}$} & \multicolumn{2}{|l|}{ LOD } & \multirow[b]{2}{*}{ Ref. } \\
\hline & & & & Cadmium & Lead & \\
\hline Glassy Carbon Electrode & $\begin{array}{l}\text { Crosslinked Chitosan and } \\
\text { Carbon Nanotubes Film }\end{array}$ & SWASV & $\begin{array}{l}\mathrm{Cd}, \mathrm{Pb} \text {, } \\
\text { and } \mathrm{Cu}\end{array}$ & $800 \mathrm{ppb}$ & $600 \mathrm{ppb}$ & 66 \\
\hline Carbon Paste Electrode & Coconut Shell Powder & ASV & $\mathrm{Cd}$ & $105 \mathrm{ppb}$ & - & 67 \\
\hline Pencil Graphite Electrode & Bismuth Film & ASV & $\mathrm{Cd}$ and $\mathrm{Pb}$ & $11 \mathrm{ppb}$ & $11.5 \mathrm{ppb}$ & 68 \\
\hline Pencil Graphite Electrode & - & DPV & $\mathrm{Pb}$ & - & $8.9 \mathrm{ppm}$ & 69 \\
\hline Glassy Carbon Electrode & $\begin{array}{l}\text { Tris }\left(2,2^{\prime} \text {-bipyridyl) }\right. \\
\text { ruthenium(II), Graphene, } \\
\text { and Nafion }\end{array}$ & DPV & $\begin{array}{l}\mathrm{Cd}, \mathrm{Pb} \text {, } \\
\text { and } \mathrm{Cu}\end{array}$ & $49 \mathrm{ppb}$ & $48 \mathrm{ppb}$ & 70 \\
\hline Glassy Carbon Electrode & $\begin{array}{l}\text { Gold Nanoparticles, } \\
\text { Hexaammineruthenium, } \\
\text { and Nafion }\end{array}$ & ASV & $\mathrm{Cd}$ and $\mathrm{Pb}$ & $45 \mathrm{ppb}$ & $200 \mathrm{ppb}$ & 71 \\
\hline Indium Tin Oxide Electrode & {$\left[\mathrm{Ru}\left(\mathrm{NH}_{3}\right)^{6}\right]^{3+}$ and Nafion } & ASV & $\begin{array}{l}\mathrm{Cd}, \mathrm{Pb} \text {, } \\
\text { and } \mathrm{Zn}\end{array}$ & $500 \mathrm{ppb}$ & $500 \mathrm{ppb}$ & 72 \\
\hline Graphene Paste Electrode & $\begin{array}{l}\text { Coconut Husk Activated } \\
\text { Carbon }\end{array}$ & ASV & $\mathrm{Cd}$ and $\mathrm{Pb}$ & $56 \mathrm{ppb}$ & $44 \mathrm{ppb}$ & 73 \\
\hline Graphene Paste Electrode & Silver Nanoparticles & ASV & $\begin{array}{l}\mathrm{Cd}, \mathrm{Pb} \text {, } \\
\text { and } \mathrm{Cu}\end{array}$ & $17 \mathrm{ppb}$ & $12 \mathrm{ppb}$ & 74 \\
\hline Battery Graphite Electrode & - & ASV & $\mathrm{Cd}$ and $\mathrm{Pb}$ & $115.37 \mathrm{ppb}$ & $112.1 \mathrm{ppb}$ & This work \\
\hline Battery Graphite Electrode & $\begin{array}{l}\text { Bismuth, MWCNT, and } \\
\text { Nafion }\end{array}$ & & $\begin{array}{l}\mathrm{Cd}, \mathrm{Pb}, \\
\text { and } \mathrm{Cu}\end{array}$ & $1.06 \mathrm{ppb}$ & $0.72 \mathrm{ppb}$ & \\
\hline
\end{tabular}

Table 2. Performance comparison of the bare and modified GE with other works.

Limits of detection. The limit of detection (LOD) of the bare electrode was found to be $115.37 \mathrm{ppb}$ for $\mathrm{Cd}^{2+}$ and $112.10 \mathrm{ppb}$ for $\mathrm{Pb}^{2+}$ while that of the modified electrode was found to be $1.06 \mathrm{ppb}$ for $\mathrm{Cd}^{2+}$ and $0.72 \mathrm{ppb}$ for $\mathrm{Pb}^{2+}$. The LOD of the fabricated bare and modified graphite electrode in this study were compared with similar electrodes from previous works in literature as shown in Table 2. The obtained detection limits of the fabricated modified electrode for both heavy metals were superior to most of the previous works, much more when the difference in the purity of the electrodes are taken into consideration since the graphite rod was not originally made as a sensor unlike the analytical grade electrodes such as the GCE.

\section{Conclusions}

Graphite rods from waste zinc-carbon batteries were modified with bismuth, multi-walled carbon nanotubes, and Nafion and were successfully used to detect cadmium and lead ions via ASV. Among the five brands used for detection, the Eveready Heavy Duty exhibited the highest anodic current peaks for both heavy metals. The drop-coating method used in the study was successful in modifying the surface of the bare electrode with BiNPs, MWCNTs, and Nafion as evidenced by the SEM micrographs and EDX analysis results. Among the nine combinations of modifiers, $1 \mathrm{mg}$ BiNPs and $1 \mathrm{mg}$ MWCNTs mixed in a $5 \mathrm{~mL}$ Nafion-ethanol solution resulted with the highest anodic current peaks for $\mathrm{Cd}$ and $\mathrm{Pb}$. Modification of the electrode surface remarkably enhanced the voltammetric response of the heavy metals which can be attributed to the synergetic effects of BiNP, MWCNT and Nafion. The calibration curves of the bare electrode exhibited excellent linearity from $100 \mathrm{ppb}$ to $1000 \mathrm{ppb}$, while the modified electrode showed excellent linearity from $5 \mathrm{ppb}$ to $1000 \mathrm{ppb}$. This, in turn, gave low detection limits (115.37 ppb and 112.1 ppb for cadmium and lead, respectively, for the bare electrode and $1.06 \mathrm{ppb}$ and 0.72 ppb for cadmium and lead, respectively for the modified electrode) which are the desired figures of merit. The modified graphite electrode was successfully utilized for the detection of $\mathrm{Cd}^{2+}$ and $\mathrm{Pb}^{2+}$ in herbal food supplement samples with good agreement to the results obtained by atomic absorption spectroscopy. Thus, the electrochemical sensor developed in this study is not only cost-effective but environment-friendly as well. Modification of the graphite electrode with other materials and its capability of detecting species other than heavy metals may be further explored.

\section{Data availability}

The datasets generated during and/or analysed during the current study are available from the corresponding author on reasonable request. 
Received: 9 February 2019; Accepted: 15 November 2019;

Published online: 06 December 2019

\section{References}

1. He, Z. L., Yang, X. E. \& Stoffella, P. J. Trace elements in agroecosystems and impacts on the environment. Journal of Trace Elements in Medicine and Biology 19(2-3), 125-140, https://doi.org/10.1016/j.jtemb.2005.02.010 (2005).

2. Shallari, S. Heavy metals in soils and plants of serpentine and industrial sites of Albania. The Science of The Total Environment 209(2-3), 133-142, https://doi.org/10.1016/s0048-9697(97)00312-4 (1998).

3. Jabeen, S., Shah, M., Khan, S. \& Hayat, M. Determination of major and trace elements in ten important folk therapeutic plants of Haripur basin, Pakistan. Journal of Medicinal Plants Research 4(7), 559-566 (2010).

4. Khan, A. A. P., Khan, A., Rahman, M., Asiri, A. \& Oves, M. Lead sensors development and antimicrobial activities based on graphene oxide/carbon nanotube/poly(O-toluidine) nanocomposite. International Journal of Biological Macromolecules 89, 198-205 (2016).

5. Khan, S. B., Rahman, M., Marwani, H., Asiri, A. \& Alamry, K. An assessment of zinc oxide nanosheets as a selective adsorbent for cadmium. Nanoscale Research Letters 8, 377-385 (2013).

6. Rahman, M. et al. Low dimensional Ni-ZnO nanoparticles as marker of toxic lead ions for environmental remediation. Journal of Industrial and Engineering Chemistry 20, 1071-1078 (2014).

7. Khan, S. B. et al. $\mathrm{Co}_{3} \mathrm{O}_{4}$ co-doped $\mathrm{TiO}_{2}$ nanoparticles as a selective marker of lead in aqueous solution. New Journal of Chemistry 37, 2888-2893 (2015).

8. Ahmad, I. et al. Crystal structure of $\mathrm{N}^{\prime}-[(\mathrm{E})$-(2-hydroxynaphthalen-1-yl) methylidene] benzenesulfonohydrazide (HNMBSH) and its application as $\mathrm{Pb}^{2+}$ ion sensor by its fabrication onto glassy carbon electrode. Inorganica Chimica Acta 467, 297-306 (2017).

9. Rahman, M., Khan, S. B., Asiri, A., Marwani, H. \& Qusti, A. Selective detection of toxic Pb(II) ions based on wet-chemically prepared nanosheets integrated $\mathrm{CuO}-\mathrm{ZnO}$ nanocomposites. Composites B Part: Engineering 54, 215-223 (2013).

10. Arshad, M. N. et al. Fabrication of cadmium ionic sensor based on (E)-4-Methyl-N'-(1-(pyridin-2-yl)ethylidene) benzenesulfonohydrazide (MPEBSH) by electrochemical approach. Journal of Organometallic Chemistry 827, 49-55 (2017).

11. Hussein, M. et al. Nanocomposite based functionalized Polyethersulfone and conjugated ternary ZnYCdO nanomaterials for the fabrication of selective $\mathrm{Cd}^{2+}$ sensor probe. Journal of Polymer Research 25, 262 (2018).

12. El-Shishtawy, R. et al. Development of $\mathrm{Cd}^{2+}$ sensor based on BZNA/Nafion/Glassy carbon electrode by electrochemical approach. Chemical Engineering Journal 352, 225-231 (2018).

13. Khan, A. et al. Toward Facile Preparation and Design of Mulberry-Shaped Poly(2-methylaniline)-Ce ${ }_{2}\left(\mathrm{WO}_{4}\right)_{3} @ \mathrm{CNT} \mathrm{Nanocomposite}$ and Its Application for Electrochemical $\mathrm{Cd}^{2+}$ Ion Detection for Environment Remediation. Polymer Plastics Technology and Engineering 57, 335-345 (2018).

14. Awual, M. R. et al. Efficient detection and adsorption of cadmium(II) ions using innovative nano-composite materials. Chemical Engineering Journal 343, 118-127 (2018).

15. Awual, M. R. et al. Facile mercury detection and removal from aqueous media involving ligand impregnated conjugate nanomaterials. Chemical Engineering Journal 290, 243-251 (2016).

16. Hussain, M., Rahman, M., Arshad, M. \& Asiri, A. $\mathrm{Hg}^{2+}$ Sensor Development Based on (E)-N'-NitrobenzylideneBenzenesulfonohydrazide (NBBSH) Derivatives Fabricated on a Glassy Carbon Electrode with a Nafion Matrix. ACS Omega 2, 420-43 (2017).

17. Arshad, M. N. et al. Fabrication of cadmium ionic sensor based on (E)-4-Methyl-N'-(1-(pyridin-2-yl)ethylidene) benzenesulfonohydrazide (MPEBSH) by electrochemical approach. Journal of Organometallic Chemistry 827, 49-55 (2017).

18. Makedonski, L., Peycheva, K. \& Stancheva, M. Determination of heavy metals in selected black sea fish species. Food Control 72, 313-318, https://doi.org/10.1016/j.foodcont.2015.08.024 (2017).

19. Khumaeni, A., Tani, M., Kurihara, K., Kagawa, K. \& Niki, H. Coarse Metal Powder-Assisted pulsed $\mathrm{CO}_{2}$ Laser-induced Breakdown Spectroscopy for the Direct Determination of Heavy Metals in Soil. Analytical Letters 50(12), 1992-1999, https://doi.org/10.1080/0 0032719.2016.1254222 (2017).

20. Bakar, N. F., Zin, N. M., Tuan Siti, M., Long Tuan, K. \& Santhanam, J. Commercial Herbal Slimming Products: Evaluation of Heavy Metals and Microorganism Contamination at Different Batch Production. Jurnal Sains Kesihatan Malaysia 15(01), 7-18, https://doi. org/10.17576/jskm-2017-1501-02 (2017).

21. Azmi, N. \& Low, S. Investigating film structure of membrane-based colorimetric sensor for heavy metal detection. Journal of Water Process Engineering 15, 37-42, https://doi.org/10.1016/j.jwpe.2016.04.004 (2017).

22. Heena et al. Determination of cobalt(II), nickel(II) and palladium(II) Ionsviafabric phase sorptive extraction in combination with high-performance liquid chromatography-UV detection. Separation Science and Technology 52(1), 81-90, https://doi.org/10.1080/ 01496395.2016.1232273 (2016).

23. Palisoc, S., Natividad, M., DeVera, P. D. \& Tuason, B. S. Determination of Cadmium $\left(\mathrm{Cd}^{2+}\right)$ and $\mathrm{Zinc}\left(\mathrm{Zn}^{2+}\right)$ via Anodic Stripping Voltammetry with $\left[\mathrm{Ru}\left(\mathrm{NH}_{3}\right)^{6}\right]^{3+} /$ Nafion Modified Electrodes. Philippine Science Letters 7(2), 372-375 (2014).

24. Palisoc, S., Natividad, M., DeVera, P. D. \& Tuason, B. S. Determination of Lead $\left(\mathrm{Pb}^{2+}\right)$ by Anodic Stripping Voltammetry Based on $\left[\mathrm{Ru}\left(\mathrm{NH}_{3}\right)^{6}\right]^{3+} /$ Nafion Modified Electrodes. Journal of New Materials for the Electrochemical Systems 17(4), 205-208 (2014).

25. Palisoc, S., Natividad, M. \& Tan, C. Voltammetric determination of copper and zinc in water using a Ruthenium bipyridyl/Nafionmodified indium tin oxide-coated glass electrode. Journal of New Materials for Electrochemical Systems 20(3), 89-149, https://doi. org/10.14447/jnmes.v20i3.261 (2017).

26. Palisoc, S. T., Natividad, M. T., Martinez, N. M., Ramos, R. M., \& Kaw, K. A. Fabrication and electrochemical study of $\left[\mathrm{Ru}\left(\mathrm{NH}_{3}\right)^{6}\right]^{3+}$ / Nafion modified electrodes for the determination of trace amounts of $\mathrm{Pb}^{2+}, \mathrm{Cd}^{2+}$, and $\mathrm{Zn}^{2+}$ via anodic stripping voltammetry. E-Polymers, 16(2). https://doi.org/10.1515/epoly-2015-0210 (2016).

27. Yuan, S., Chen, W. \& Hu, S. Simultaneous determination of cadmium (II) and lead (II) with clay nanoparticles and anthraquinone complexly modified glassy carbon electrode. Talanta 64(4), 922-928 (2004).

28. Carbon - Vitreous GF65427587. (n.d.). Retrieved from https://www.sigmaaldrich.com/catalog/product/aldrich/ gf65427587? lang=enion $=\mathrm{PH}$

29. Pokpas, K., Zbeda, S., Jahed, N., Mohamed, N. \& Baker, P. G. International Journal of Electrochemical Science 9, 736-759 (2014).

30. Overview: Eveready Industry India Ltd. Retrieved from http://www.conceptsecurities.com/download.php?id=14\&type=latest (4 October 2017).

31. Ng, K. L., Lee, S. M., Khor, S. M. \& Tan, G. H. Electrochemical Preparation and Characterization of a Gold Nanoparticles Graphite Electrode: Application to Myricetin Antioxidant Analysis. Analytical Sciences 31(10), 1075-1081, https://doi.org/10.2116/ analsci.31.1075 (2015).

32. Wring, S. A. \& Hart, J. P. Chemically modified, carbon-based electrodes and their application as electrochemical sensors for the analysis of biologically important compounds. A review. The Analyst 117(8), 1215, https://doi.org/10.1039/an9921701215 (1992).

33. Appy, D. et al. Transition metals on the $\left(\begin{array}{llll}0 & 0 & 0 & 1\end{array}\right)$ surface of graphite: Fundamental aspects of adsorption, diffusion, and morphology. Progress in Surface Science 89(3-4), 219-238, https://doi.org/10.1016/j.progsurf.2014.08.001 (2014).

34. Rahman, M. et al. Acetone sensor based on solvothermally prepared ZnO doped with Co3O4 nanorods. Microchim. Acta 180(2013), 675-685 (2013). 
35. Umar, A., Rahman, M., Kim, S. H. \& Hahn, Y. B. Zinc oxide nanonail based chemical sensor for hydrazine detection. Chemical Communications 2, 166-168 (2008).

36. Rahman, M. \& Asiri, A. Fabrication of highly sensitive ethanol sensor based on doped nanostructure materials using tiny chips. RSC Advances 5, 63252-63263 (2015).

37. Awual, M. R. et al. Ligand field effect for Dysprosium(III) and Lutetium(III) adsorption and EXAFS coordination with novel composite nanomaterials. Chemical Engineering Journal 320, 427-435 (2017).

38. Khan, A. A. P., Khan, A., Rahman, M., Asiri, A. \& Oves, M. Sensor development of 1,2 Dichlorobenzene based on polypyrole/Cudoped $\mathrm{ZnO}(\mathrm{PPY} / \mathrm{CZO})$ nanocomposite embedded silver electrode and their antimicrobial studies. Internatiobal Journal of Biological Macromolecules 98, 256-267 (2017).

39. Hussain, M. M., Rahman, M. \& Asiri, A. Ultrasensitive and selective 4-aminophenol chemical sensor development based on nickel oxide nanoparticles decorated carbon nanotube nanocomposites for green environment. Journal of Environmental Science 53, 27-38 (2017).

40. Rahman, M., Ahmed, J. \& Asiri, A. A glassy carbon electrode modified with $\gamma-\mathrm{Ce}_{2} \mathrm{~S}_{3}$-decorated CNT nanocomposites for uric acid sensor development: a real sample analysis. RSC Advances 7, 14649-14659 (2017).

41. Alam, M. et al. Ultra-sensitive 2-nitrophenol detection based on reduced graphene oxide/ZnO nanocomposites. Journal of Electroanalytical Chemistry 788, 66-73 (2017).

42. Rahman, M. et al. Hydrazine sensors development based on a glassy carbon electrode modified with a nanostructured $\mathrm{TiO}_{2}$ films by electrochemical approach. Microchimica Acta 184, 2123-2129 (2017).

43. Rahman, M., Alam, M. M., Asiri, A. \& Islam, M. A. Ethanol sensor development based on ternary-doped metal oxides (CdO/ZnO/ $\mathrm{Yb}_{2} \mathrm{O}_{3}$ ) nanosheets for environmental safety. RSC Advances 7, 22627-22639 (2017).

44. Rahman, M., Alam, M. M., Asiri, A. \& Islam, M. A. Fabrication of selective chemical sensor with ternary $\mathrm{ZnO} / \mathrm{SnO} 2 / \mathrm{Yb} 2 \mathrm{O} 3$ nanoparticles. Talanta 170, 215-223 (2017).

45. Gholivand, M. B., Ahmadi, E. \& Haseli, M. A novel voltammetric sensor for nevirapine, based on modified graphite electrode by MWCNs/poly(methylene blue)/gold nanoparticle. Analytical Biochemistry 527, 4-12, https://doi.org/10.1016/j.ab.2017.03.018 (2017).

46. Dagar, K. \& Pundir, C. An improved amperometric L-lactate biosensor based on covalent immobilization of microbial lactate oxidase onto carboxylated multi-walled carbon nanotubes/copper nanoparticles/polyaniline modified pencil graphite electrode. Enzyme and Microbial Technology 96, 177-186, https://doi.org/10.1016/j.enzmictec.2016.10.014 (2017).

47. Karakaya, S. \& Dilgin, Y. Flow Injection Amperometric Analysis of $\mathrm{H}_{2} \mathrm{O}_{2}$ at Platinum Nanoparticles Modified Pencil Graphite Electrode. Electroanalysis 29(6), 1626-1634, https://doi.org/10.1002/elan.201700045 (2017).

48. Mohammadi, S. Z., Beitollahi, H. \& Mousavi, M. Determination of hydroxylamine using a carbon paste electrode modified with graphene oxide nanosheets. Russian Journal of Electrochemistry 53(4), 374-379, https://doi.org/10.1134/s1023193517040097 (2017).

49. Hwang, G., Han, W., Park, J. \& Kang, S. Determination of trace metals by anodic stripping voltammetry using a bismuth-modified carbon nanotube electrode. Talanta 76(2), 301-308, https://doi.org/10.1016/j.talanta.2008.02.039 (2008).

50. Wang, N. \& Dong, X. Stripping Voltammetric Determination of $\mathrm{Pb}(\mathrm{II})$ and $\mathrm{Cd}$ (II) Based on the Multi-walled Carbon NanotubesNafion-Bismuth Modified Glassy Carbon Electrodes. Analytical Letters 41(7), 1267-1278, https://doi. org/10.1080/00032710802052817 (2008).

51. Ajayan, P. M. Nanotubes from Carbon. Chemical Reviews 99(7), 1787-1800, https://doi.org/10.1021/cr970102g (1999).

52. Britto, P. J., Santhanam, K. S., Rubio, A., Alonso, J. A. \& Ajayan, P. M. Improved Charge Transfer at Carbon Nanotube Electrodes. Advanced Materials 11(2), 154-157. https://doi.org/10.1002/(sici)1521-4095(199902)11:2<154::aid-adma154>3.0.co;2-b (1999).

53. Sanghavi, B. J. \& Srivastava, A. K. Adsorptive stripping differential pulse voltammetric determination of venlafaxine and desvenlafaxine employing Nafion-carbon nanotube composite glassy carbon electrode. Electrochimica Acta 56(11), 4188-4196, https://doi.org/10.1016/j.electacta.2011.01.097 (2011).

54. Ensafi, A. A., Jafari-Asl, M. \& Rezaei, B. A novel enzyme-free amperometric sensor for hydrogen peroxide based on Nafion/ exfoliated graphene oxide- $\mathrm{Co}_{3} \mathrm{O}_{4}$ nanocomposite. Talanta 103,322-329, https://doi.org/10.1016/j.talanta.2012.10.063 (2013).

55. WHO. WHO Guidelines on Safety Monitoring of Herbal Medicines in Pharmacovigilance Systems. (World Health Organization, Geneva, Switzerland, 2004).

56. Raynor, D. K., Dickinson, R., Knapp, P., Long, A. F. \& Nicolson, D. J. Buyer beware? Does the information provided with herbal products available over the counter enable safe use? BMC Medicine 9(1), https://doi.org/10.1186/1741-7015-9-94 (2011).

57. Ernst, E. Toxic heavy metals and undeclared drugs in Asian herbal medicines. Trends in Pharmacological Sciences 23(3), 136-139, https://doi.org/10.1016/s0165-6147(00)01972-6 (2002).

58. Saper, R. B., Kales, S. N. \& Paquin, J. Heavy Metal Content of Ayurvedic Herbal Medicine Products. Jama 292(23), 2868, https://doi. org/10.1001/jama.292.23.2868 (2004).

59. Ragan, S. M. December (18). Harvesting Chemicals from a Battery| Make:. Retrieved from https://makezine.com/projects/ harvesting-chemicals-from-a-battery/ (2012).

60. Mamani, M., Aleixo, L., Abreu, M. \& Rath, S. Simultaneous determination of cadmium and lead in medicinal plants by anodic stripping voltammetry. Journal of Pharmaceutical and Biomedical Analysis 37, 709-713, https://doi.org/10.1016/j.jpba.2004.11.049 (2005).

61. Zhai, Z. et al. A diamond/graphite nanoplatelets electrode for anodic stripping voltammetric trace determination of $\mathrm{Zn}$ (II), Cd (II), $\mathrm{Pb}$ (II) and $\mathrm{Cu}$ (II). Applied Surface Science 457, 1192-1201, https://doi.org/10.1016/j.apsusc.2018.06.266 (2018).

62. Baghayeri, M., Amiri, A., Maleki, B., Alizadeh, Z. \& Reiser, O. A simple approach for simultaneous detection of cadmium (II) and lead (II) based on glutathione coated magnetic nanoparticles as a highly selective electrochemical probe. Sensors and Actuators B: Chemical 273, 1442-1450, https://doi.org/10.1016/j.snb.2018.07.063 (2018).

63. Dong, S. \& Wang, Y. Anodic stripping voltammetric determination of trace lead with a nafion/crown-ether film electrode. Talanta 35(10), https://doi.org/10.1016/0039-9140(88)80193-0 (1998).

64. Palisoc, S., Sow, V. A. \& Natividad, M. Fabrication of a bismuth nanoparticle/Nafion modified screen-printed graphene electrode for in situ environmental monitoring. Analytical. Methods 11, 1591-1603 (2019).

65. Khun, N. W. \& Liu, E. Linear sweep anodic stripping voltammetry of heavy metals from nitrogen doped tetrahedral amorphous carbon thin films. Electrochimica Acta 54, 2890-2898 (2008).

66. Wu, K., Lo, H., Wang, J., Yu, S. \& Yan, B. Electrochemical detection of heavy metal pollutant using crosslinked chitosan/carbon nanotubes thin film electrodes. Materials Express 7(1), 15-24, https://doi.org/10.1166/mex.2017.1351 (2017).

67. Rajawat, D. S., Kumar, N. \& Satsangee, S. P. Trace determination of cadmium in water using anodic stripping voltammetry at a carbon paste electrode modified with coconut shell powder. Journal of Analytical Science and Technology 5(1), https://doi. org/10.1186/s40543-014-0019-0 (2014).

68. Bedin, K. C. et al. Inexpensive Bismuth-Film Electrode Supported on Pencil-Lead Graphite for Determination of $\mathrm{Pb}(\mathrm{II})$ and $\mathrm{Cd}(\mathrm{II})$ Ions by Anodic Stripping Voltammetry. International. Journal of Analytical Chemistry 2018, 1-9, https://doi. org/10.1155/2018/1473706 (2018).

69. Elobeid, W. \& Elbashir, A. Development and Validation of Differential Pulse Anodic Stripping Voltammetric Method for Determination of Lead (II) in Ground Water Using a Pencil Graphite Electrode. ECronicon Open Access (2018). 
70. Palisoc, S. T., Uy, D. J., Natividad, M. T. \& Lopez, T. B. Determination of heavy metals in mussel and oyster samples with tris (2,2'-bipyridyl) ruthenium (II)/graphene/Nafion modified glassy carbon electrodes. Materials Research Express 4(11), 116406, https://doi.org/10.1088/2053-1591/aa9745 (2017).

71. Palisoc, S., Causing, A. M. \& Natividad, M. Gold nanoparticle/hexaammineruthenium/Nafion modified glassy carbon electrodes for trace heavy metal detection in commercial hair dyes. Analytical Methods 9(29), 4240-4246, https://doi.org/10.1039/c7ay01114h (2017).

72. Palisoc, S. T., Kaw, K. A., Natividad, M. T. \& Robles, J. C. Spin Coated Hexaammineruthenium(III)/Nafion/ITO electrodes for the Determination of Lead(II) and Cadmium(II) via Anodic Stripping Voltammetry. Journal of New Materials for Electrochemical Systems 20(2), 077-082, https://doi.org/10.14447/jnmes.v20i2.301 (2017).

73. Palisoc, S. T., Estioko, L. C. \& Natividad, M. T. Voltammetric determination of lead and cadmium in vegetables by graphene paste electrode modified with activated carbon from coconut husk. Materials Research Express 5(8), 085035, https://doi.org/10.1088/20531591/aad43a (2018).

74. Palisoc, S., Lee, E., Natividad, M. \& Racines, L. Silver Nanoparticle Modified Graphene Paste Electrode for the Electrochemical Detection of Lead, Cadmium and Copper. International Journal of Electrochemical Science, 8854-8866, https://doi. org/10.20964/2018.09.03 (2018)

\section{Author contributions}

S.T.P. and M.T.N. conceptualized and designed the work, interpreted the results and were part of the manuscript preparation. R.I. M.V. performed the measurements and participated in the manuscript preparation.

\section{Competing interests}

The authors declare no competing interests.

\section{Additional information}

Correspondence and requests for materials should be addressed to M.N.

Reprints and permissions information is available at www.nature.com/reprints.

Publisher's note Springer Nature remains neutral with regard to jurisdictional claims in published maps and institutional affiliations.

(c) Open Access This article is licensed under a Creative Commons Attribution 4.0 International License, which permits use, sharing, adaptation, distribution and reproduction in any medium or format, as long as you give appropriate credit to the original author(s) and the source, provide a link to the Creative Commons license, and indicate if changes were made. The images or other third party material in this article are included in the article's Creative Commons license, unless indicated otherwise in a credit line to the material. If material is not included in the article's Creative Commons license and your intended use is not permitted by statutory regulation or exceeds the permitted use, you will need to obtain permission directly from the copyright holder. To view a copy of this license, visit http://creativecommons.org/licenses/by/4.0/.

(C) The Author(s) 2019 